\title{
Parasitological monitoring of European bison (Bison bonasus) from three forests of north-eastern Poland between 2014 and 2016
}

\author{
Michał K. Krzysiak ${ }^{1,2}$, Aleksander W. Demiaszkiewicz ${ }^{3}$, \\ Magdalena Larska ${ }^{4}$, Jarosław Tomana ${ }^{5}$, Krzysztof Anusz ${ }^{6}$ \\ ${ }^{1}$ Białowieża National Park, 17-230 Białowieża, Poland \\ ${ }^{2}$ Institute of Forest Sciences, Faculty of Civil Engineering and Environmental Sciences, \\ Bialystok University of Technology, 15-351 Białystok, Poland \\ ${ }^{3} \mathrm{~W}$. Stefański Institute of Parasitology, Polish Academy of Sciences, 00-818 Warsaw, Poland \\ ${ }^{4}$ Department of Virology, National Veterinary Research Institute, 24-100 Puławy, Poland \\ ${ }^{5}$ Veterinary Clinic, 43-200 Pszczyna, Poland \\ ${ }^{6}$ Department of Food Hygiene and Public Health Protection, Faculty of Veterinary Medicine, \\ Warsaw University of Life Sciences, 02-776 Warsaw, Poland \\ michal.krzysiak@bpn.com.pl
}

Received: September 3, $2019 \quad$ Accepted: March 2, 2020

\begin{abstract}
Introduction: Common parasites of the European bison include gastro-intestinal and pulmonary nematodes, liver flukes (Fasciola hepatica), tapeworms, and protozoa of the genus Coccidia. This study compared the extensiveness and intensities of European bison parasitic invasions in three north-eastern Polish forests in different seasons and queried the role of parasitological monitoring in sanitary and hygienic control of feeding places. Material and Methods: Faecal samples were collected in the Białowieża, Knyszyńska, and Borecka Forests between 2014 and 2016, as were some from an area neighbouring the Białowieża Forest outside the Natura 2000 protected area. Parasites were detected in individual samples with the flotation, decanting and Baermann methods. Results: The eggs of Trichostrongylidae, Aonchotheca sp., Nematodirus sp., Strongyloides spp., Trichuris sp., Moniezia spp., and Fasciola hepatica; the larvae of Dictyocaulus viviparus; and the oocytes of Eimeria spp. were identified. Significant variation in invasion intensity and diversity was seen by origin and season. The relationships were assessed first by univariable tests and next multivariately, when origin and season emerged as the major risk factors for exposure to most of the parasites. Conclusion: The differences in the level of parasitic infection between the forests did not have implications for its sufficiency to cause clinical symptoms. However, the associations and risk factors found enable the necessary preventive measures to be taken to protect the E. bison from exposure or decrease the risks. Additionally, parasitological monitoring is appropriate as the method of sanitary and hygienic control of European bison winter feeding places. Threats to public health through adventitious invasions by zoonotic factors such as $F$. hepatica have been identified.
\end{abstract}

Keywords: European bison, parasites, parasitological monitoring, zoonosis.

\section{Introduction}

Wildlife commonly carry parasitic invasions (4). European bison as the largest free-living land mammals in Europe are no exception, and they are also exposed to them as previously described comprehensively $(7,12)$. The most common European bison parasites are gastrointestinal nematodes, which were found in almost $100 \%$ of animals tested (7). The most serious health problem for European bison are invasions of the pulmonary nematode Dictyocaulus viviparus and the liver fluke Fasciola hepatica (16). Invasions of the gastrointestinal tract by protozoa of the genus Coccidia are also not without significance for the general health of animals (27). The last wild Lowland European bison was killed in the Białowieża Primeval Forest in 1919, ten years before the restitution was launched. All the individuals living worldwide today are descendants of those kept in captivity, through which the restitution of the species was achieved (19). Therefore, it is uncertain whether 
European bison parasites are specific to the species. However, it seems more likely that European bison assimilated the parasites of free-ranging and domesticated ruminants (9). The purpose of this study was to test any possible differences in the extensiveness and intensities of parasitic invasions in European bison based on coproscopic examination of European bison faeces collected intravitally. The number of eggs, larvae, and oocytes excreted in three north-eastern Polish forests was analysed statistically to verify the impact of season and origin. The subject of possible threats to public health through adventitious invasions by zoonotic factors was also taken up.

\section{Material and Methods}

Faecal sample collection. The study included freeranging European bison from the area of north-eastern Poland. The material for parasitological monitoring was collected between 2014 and 2016 in three forests: the Białowieża Forest $(\mathrm{BiF})$ and the Knyszyńska Forest $(\mathrm{KnF})$ located in Podlasie Province and Borecka (BoF) in Warmian-Masurian Province (Table 1). European bison faecal samples from BPF were collected in 2014 $(n=133), 2015(n=56)$, and $2016(n=51)$. Additionally, some samples from European bison were collected from a neighbouring area located outside the Natura 2000 protected area of the Białowieża Forest between 2014 and 2016. The samples from the Knyszyńska and Borecka Forests were collected in 2014 ( $n=18$ and $n=12$, respectively) and 2015 ( $n=89$ and $n=14$, respectively). Samples were collected in the European bison habitats, ensuring that the collected material was fresh and came from separate individuals living in separate herds. This procedure was aimed at minimising the risk of sample contamination by soil nematodes and ensuring the uniqueness of the research material in order to properly assess the species composition of parasites.

Parasitological methods. Diagnosis was performed using the flotation, decanting, and Baermann methods, and each of the collected samples was tested individually (13). The number of eggs of nematodes and tapeworms and oocysts of Coccidia was determined in $3 \mathrm{~g}$ of faeces, while the number of larvae of lungworms was ascertained in $5 \mathrm{~g}$. As described previously $(4,6,18)$, intravital parasitological diagnosis was mainly based on coproscopy analyses.
Extensiveness and intensity of invasion were determined on the basis of the number of excreted eggs, larvae and oocysts. Extensiveness of invasion was determined as a proportion of animals in the herd, which had at least one egg, larva, or oocyst of the specified parasites evident in the faeces. The intensity was defined as the arithmetic mean of the minimal and maximal number of eggs, larvae, or oocysts in the faeces of animals in the herd. A $3 \mathrm{~g}$ amount of the individual sample was used to test for the presence of eggs of Trichostrongylidae, Nematodirus, and Moniezia and oocysts of Eimeria spp. For this purpose, the direct flotation method was used with modifications consisting of using a centrifuge and replacing the saturated $\mathrm{NaCl}$ solution with sucrose one (13). The presence of Fasciola hepatica eggs was investigated using the decantation method due to the weight of the eggs, also in a $3 \mathrm{~g}$ mass of faecal sample (13). Baermann's method was used to identify different stages of lungworm larvae of Dictyocaulus in $5 \mathrm{~g}$ of faeces (13).

Statistical analysis. Statistical analysis was performed using Statistica v12.5 (PL) (Statsoft, Cracow, Poland) and STATA v. 13.0 software (StataCorp, College Station, TX, USA). The data set was prepared using as two outcomes numbers of parasite forms, to study the intensity of invasion, and presence/absence of the parasite, a binomial variable to study the prevalence of invasion. The predictors included the origin (one of the four populations) and season (autumn denoting the autumns 2014 and 2015, winter that of 2016, and spring exclusively 2015). The normality of the data distribution was evaluated using quantile plots and the Shapiro-Wilk test. The non-parametric Kruskal-Wallis test was used to verify the statistical significance of the origin and season for the numbers of parasite eggs and oocysts of Eimeria spp. For the graphical illustration by box plot, all gastro-intestinal nematodes were joined into one group. The cross-correlations between the densities and prevalence of individual parasites were assessed by Spearman rank and $\chi^{2}$ tests, respectively. Generalised linear mixed models (GLMMs) using Poisson and binomial error structures were developed for count data of parasites in each group and the prevalence of the parasite groups, respectively, with origin and season as explanatory variables. Possible confounding and clustering were analysed by checking the variance of the covariates as described by Dohoo et al. (8). Final models included only significant factors $(\mathrm{P} \leq 0.05)$.

Table 1. The numbers of faecal samples collected by location and season

\begin{tabular}{lccccc}
\hline \multirow{2}{*}{ Season } & \multicolumn{5}{c}{ Location } \\
\cline { 2 - 6 } & Borecka Forest & Knyszyńska Forest & Białowieża Forest & BiF neighbouring region & Total \\
\hline Autumn 2014 & 12 & 18 & 78 & 50 & 158 \\
Autumn 2015 & 0 & 65 & 0 & 0 & 65 \\
Spring 2015 & 14 & 24 & 20 & 36 & 94 \\
Winter 2016 & 0 & 0 & 41 & 10 & 51 \\
\hline Total & 26 & 107 & 139 & 96 & 368 \\
\hline
\end{tabular}


Table 2. The numbers of different gastro-intestinal nematodes, Fasciola hepatica eggs, Dictyocaulus viviparus larvae, and Eimeria spp. oocysts and the parasite prevalence in European bison from the Białowieża Forest $(\mathrm{n}=139)$ and its neighbouring area ( $\mathrm{n}=96)$ and the Knyszyńska $(n=107)$ and Borecka $(n=26)$ Forests collected in the autumns of 2014 and $2015(n=223)$, winter $2016(n=51)$, and spring $2015(n=94)$

\begin{tabular}{|c|c|c|c|c|c|c|c|c|}
\hline \multirow{3}{*}{$\begin{array}{l}\text { Parasite species } \\
\text { (adult gastro-intestinal } \\
\text { nematodes except } \\
\text { where noted) }\end{array}$} & & \multicolumn{7}{|c|}{ Variables } \\
\hline & & \multicolumn{4}{|c|}{ Origin } & \multicolumn{3}{|c|}{ Season } \\
\hline & & $\begin{array}{c}\text { Białowieża } \\
\text { Forest }(\mathrm{BiF})\end{array}$ & $\begin{array}{c}\mathrm{BiF} \\
\text { neighbouring } \\
\text { area }\end{array}$ & $\begin{array}{l}\text { Knyszyńska } \\
\text { Forest }\end{array}$ & $\begin{array}{l}\text { Borecka } \\
\text { Forest }\end{array}$ & Autumn & Winter & Spring \\
\hline \multirow{4}{*}{ Trichostrongylidae } & $n^{\mathrm{a}}$ & 37.9 & 98.2 & 25.1 & 14.1 & 14.2 & 43 & 131.9 \\
\hline & (range) & $(1-1150)$ & $(1-1196)$ & $(1-305)$ & $(1-45)$ & $(1-98)$ & $(1-448)$ & $(1-1196)$ \\
\hline & $\%^{\mathrm{c}}$ & 95.7 & 93.7 & 94.4 & 92.3 & 92 & 100 & 98 \\
\hline & $\left(\mathrm{SD}^{\mathrm{b}}\right)$ & $(20.4)$ & $(24.3)$ & $(23.1)$ & $(27.2)$ & $(27.3)$ & $(0)$ & $(14.5)$ \\
\hline \multirow{4}{*}{ Aonchotheca spp. } & $n^{\mathrm{a}}$ & 5.3 & 4.2 & 1.3 & 6.2 & 3.8 & 2 & 3.1 \\
\hline & (range) & $(1-82)$ & $(1-58)$ & $(1-8)$ & $(1-28)$ & $(1-82)$ & $(1-20)$ & $(1-79)$ \\
\hline & $\%^{\mathrm{c}}$ & 54.7 & 59.4 & 7.4 & 34.6 & 43.5 & 43.1 & 32.9 \\
\hline & $\left(\mathrm{SD}^{\mathrm{b}}\right)$ & $(50)$ & $(49.4)$ & (26.4) & $(48.5)$ & -49.7 & $(50)$ & $(47.2)$ \\
\hline \multirow{4}{*}{ Nematodirus spp. } & $n^{\mathrm{a}}$ & 0.06 & 1.1 & 0.02 & $(10.0)$ & 0.1 & 1 & 0.4 \\
\hline & (range) & $(1-4)$ & $(1-24)$ & $(1-1)$ & 0 & $(1-13)$ & $(1-24)$ & $(1-10)$ \\
\hline & $\%{ }^{c}$ & 3.6 & 19.8 & 1.9 & & 4.5 & 9.8 & 11.7 \\
\hline & $\left(\mathrm{SD}^{\mathrm{b}}\right)$ & $(18.7)$ & $(40)$ & $(13.6)$ & 0 & $(20.7)$ & $(30)$ & $(32.3)$ \\
\hline \multirow[b]{2}{*}{ Strongyloides spp. } & $\begin{array}{l}n^{\mathrm{a}} \\
\text { (range) }\end{array}$ & 0 & 0 & $\begin{array}{c}0.1 \\
(1-5)\end{array}$ & 0 & $\begin{array}{c}0.05 \\
(1-5)\end{array}$ & 0 & 0 \\
\hline & $\begin{array}{l}\% c \\
\left(\mathrm{SD}^{\mathrm{b}}\right)\end{array}$ & 0 & 0 & $\begin{array}{c}2.8 \\
(16.6)\end{array}$ & 0 & $\begin{array}{c}1.3 \\
(11.5)\end{array}$ & 0 & 0 \\
\hline \multirow{4}{*}{ Trichuris spp. } & $n^{\mathrm{a}}$ & 2.1 & 19.8 & 0.6 & 0 & 1.7 & 10.3 & 14.3 \\
\hline & (range) & $(1-152)$ & $(1-305)$ & $(1-61)$ & 0 & $(1-136)$ & $(1-249)$ & $(1-305)$ \\
\hline & $\% \mathrm{c}$ & 5.8 & 17.7 & 1.9 & 0 & 3.6 & 11.8 & 13.8 \\
\hline & $\left(\mathrm{SD}^{\mathrm{b}}\right)$ & $(23.3)$ & $(38.4)$ & (13.6) & 0 & (18.6) & $(32.5)$ & $(34.7)$ \\
\hline \multirow{4}{*}{ Moniezia spp. } & $n^{\mathrm{a}}$ & 1.7 & 14.3 & 4.5 & & 2.1 & 6.5 & 14 \\
\hline & (range) & $(1-142)$ & $(1-304)$ & $(1-267)$ & 0 & $(1-267)$ & $(1-142)$ & $(0-304)$ \\
\hline & $\% c$ & 8.6 & 15.6 & 3.7 & & 4 & 17.6 & 13.8 \\
\hline & $\left(\mathrm{SD}^{\mathrm{b}}\right)$ & $(28.2)$ & $(36.5)$ & (19.1) & 0 & (19.7) & $(38.5)$ & $(34.7)$ \\
\hline \multirow{4}{*}{ Eimeria spp. (oocysts) } & $n^{\mathrm{d}}$ & 45.4 & 99.2 & 10.8 & 160.6 & 65.9 & 27.5 & 53.8 \\
\hline & (range) & $(1-748)$ & $(1-5072)$ & $(1-557)$ & $(1-1914)$ & $(1-5072)$ & $(1-391)$ & $(1-1917)$ \\
\hline & $\%^{\mathrm{d}}$ & 74.8 & 77.1 & 25.2 & 96.1 & 56 & 82.3 & 65.9 \\
\hline & $\left(\mathrm{SD}^{\mathrm{b}}\right)$ & $(43.5)$ & $(42.2)$ & $(43.6)$ & (19.6) & (49.7) & $(38.5)$ & $(47.6)$ \\
\hline \multirow{4}{*}{ Fasciola hepatica (eggs) } & $n^{\mathrm{a}}$ & 8.7 & 8.7 & 2.4 & 5.3 & 3.5 & 18.3 & 7.5 \\
\hline & (range) & $(1-403)$ & $(1-63)$ & $(1-22)$ & $(1-62)$ & $(1-63)$ & $(1-403)$ & $(1-38)$ \\
\hline & $\%^{\mathrm{c}}$ & 69.1 & 78.1 & 53.3 & 30.8 & 62.3 & 58.8 & 71.3 \\
\hline & $\left(\mathrm{SD}^{\mathrm{b}}\right)$ & (46.4) & (41.6) & $(50.1)$ & $(47.1)$ & $(48.5)$ & (49.7) & $(45.5)$ \\
\hline \multirow{4}{*}{$\begin{array}{l}\text { Dictyocaulus viviparus } \\
\text { (larvae) }\end{array}$} & $n^{\mathrm{a}}$ & 5 & 49.8 & & 28.4 & 6 & 20.7 & 40.6 \\
\hline & (range) & $(1-173)$ & $(1-856)$ & 0 & $(1-276)$ & $(1-276)$ & $(1-176)$ & $(1-856)$ \\
\hline & $\%{ }^{c}$ & 26.6 & 55.2 & 0 & 46.1 & 14.4 & 33.3 & 56.4 \\
\hline & $\left(\mathrm{SD}^{\mathrm{b}}\right)$ & $(44.3)$ & $(50)$ & 0 & $(50.8)$ & $(35.1)$ & $(47.6)$ & (49.8) \\
\hline
\end{tabular}

${ }^{\mathrm{a}}$ - mean of egg numbers per $3 \mathrm{~g}$ of faeces; ${ }^{\mathrm{b}}-\%$ mean prevalence; ${ }^{\mathrm{c}}-$ standard deviation; ${ }^{\mathrm{d}}-$ mean of oocyst numbers per $5 \mathrm{~g}$ of faeces

\section{Results}

Trichostrongylidae were observed to be the most prevalent $(94.5 \% \pm 22.7 \mathrm{SD})$ and invasive, with 48.5 eggs found in $3 \mathrm{~g}$ of faeces on average. Fasciola hepatica, Eimeria spp., Aonchotheca sp., and Dictyocaulus viviparus were also common and were found in $64.1 \%, 62.5 \%$, $40.8 \%$, and $27.7 \%$ of faecal samples, respectively. However, the intensities of invasions were much lower for those parasites in comparison to Trichostrongylidae, except for Eimeria spp. with a mean value of 57.5 oocysts found in $5 \mathrm{~g}$ of faeces. Strongyloides spp. eggs were found only in three faecal samples collected in the Knyszyńska Forest in the autumn of 2014. Tables 1 and 2 include the descriptive statistics. The distribution of the parasitological investigation results varied by origin and the season when the samples were collected (Table 2). Interestingly, significantly more $(\mathrm{P} \leq 0.001)$ Trichostrongylidae, Trichuris sp., and Monezia spp. eggs, D. viviparus larvae, and Eimeria spp. oocysts were found in the faeces of European bison collected in the area neighbouring the Białowieża Forest than in other locations, including the Białowieża Forest itself. Moreover, the density and prevalence of Nematodirus sp., Trichuris sp., and Monezia spp. were significantly lower in the Knyszyńska and Borecka Forests than in the Białowieża Forest. Dictyocaulus viviparus larvae were not identified in any of the samples from the Knyszyńska Forest. The intensities of invasions by Trichostrongylidae, Trichuris sp., Monezia spp., and D. viviparus nematodes were considerably higher in spring.

The numbers of parasite eggs and larvae shed in European bison faeces differed significantly between the different populations (Fig. 1A) and seasons (Fig. 1B), except for those of Eimeria spp. oocysts numbers, which were comparable from autumn to spring. The average number of nematodes including the gastro-intestinal ones as well as D. viviparus was much higher in the area lying next to the Białowieża Forest than it was inside the Białowieża Forest. More intensive invasion in spring was observed for gastro-intestinal parasites and Fasciola hepatica (Fig. 1). 
The associations between all the variables were assessed, with the count variable accepted as parasite intensity (egg/larva/oocyst number) and a binomial variable standing for prevalence of parasite invasion (Table 3). In the univariable analysis, the intensity of the invasion by individual parasites differed significantly between locations, except for Strongyloides spp. The season was associated with the numbers of eggs of Trichostrongylidae, Trichuris sp., Monezia spp., Fasciola hepatica, and larvae of Dictyocaulus viviparus. Additionally, some intensities of invasions were observed to be more correlated, like those of Trichuris to Nematodirus, Trichuris sp. to Monezia spp.,
Trichostrongylidae to D. viviparus, and Eimeria spp. to Aonchotheca sp. (Table 3). Similar associations were observed for their prevalences, except for there being no correlation of Trichostrongylidae to D. viviparus. The prevalences of most parasites were dependent on the origin, except for Trichostrongylidae, Eimeria spp., and Strongyloides spp., probably because of the high percentages of European bison infected with the two first parasites and the rarity of strongyloidosis in observation. There was a significant interdependence between season and origin, however, it did not affect the development of the final models, which included both predictors.
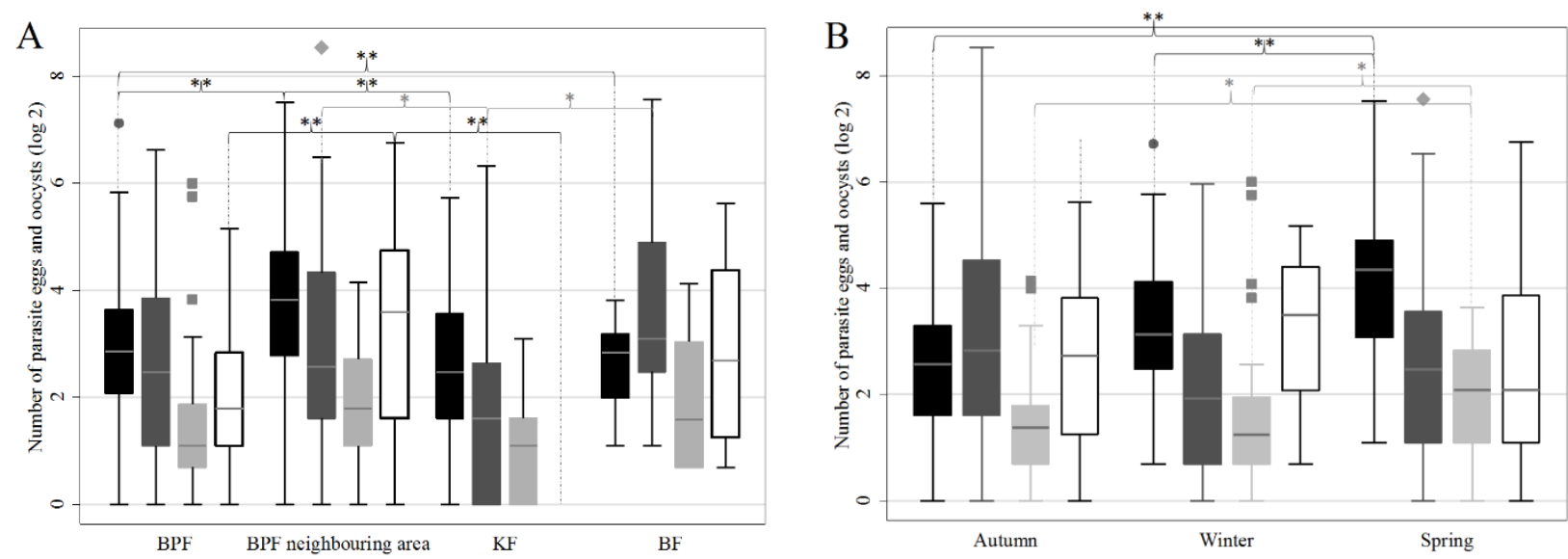

Fig. 1. Box plot of numbers of gastro-intestinal nematode eggs (black), Eimeria spp. oocysts (dark grey), Fasciola hepatica (light grey), and Dictyocaulus viviparus eggs (white) broken down by origin (A) and season (B). Boxes show the median and upper and lower quartiles, while the whiskers illustrate the data range. The additional dot, square, or diamond points stand for outliers. The statistically significant differences were verified using the Kruskal-Wallis test and are indicated with * for $\mathrm{P}$ between 0.05 and 0.001 and ** for $\mathrm{P}<0.001$

Table 3. Cross-correlations between the explanatory variables and outcomes - prevalence and intensity of invasion

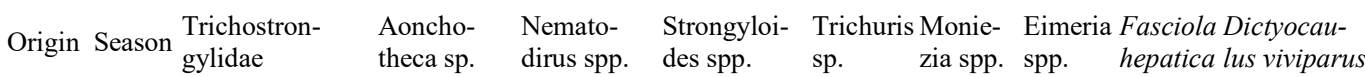

\begin{tabular}{|c|c|c|c|c|c|c|c|c|c|c|c|c|}
\hline Origin & 1 & - & $27.1 * *$ & $68.5 * *$ & $33.2 * *$ & 7.3 & $22.9 * *$ & $12.0 *$ & $92.3 * *$ & $37.2 * *$ & $86.4 * *$ & \\
\hline Season & $72.1 * *$ & 1 & $102.1 * *$ & 4.5 & 6.0 & 1.9 & $12.0 *$ & $15.0 * *$ & 3.2 & $13.4^{*}$ & $56.4 * *$ & \\
\hline $\begin{array}{l}\text { Trichostron- } \\
\text { gylidae }\end{array}$ & 0.73 & $7.9 *$ & 1 & $0.15^{*}$ & $0.22 * *$ & -0.09 & $0.29 * *$ & $0.27 * *$ & $0.13^{*}$ & $0.25 * *$ & $0.38 * *$ & 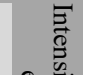 \\
\hline Aonchotheca sp. & $74.4 * *$ & 3.2 & $5.8^{*}$ & 1 & 0.11 & -0.07 & 0.10 & 0.07 & $0.38 * *$ & $0.16^{*}$ & $0.15^{*}$ & \\
\hline $\begin{array}{l}\text { Nematodirus } \\
\text { spp. }\end{array}$ & $32.6 * *$ & $5.9 *$ & 1.6 & $7.0^{*}$ & 1 & -0.02 & $0.46 * *$ & $0.35^{* *}$ & $0.16^{*}$ & $0.22 * *$ & $0.26 * *$ & 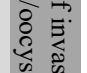 \\
\hline $\begin{array}{l}\text { Strongyloides } \\
\text { spp. }\end{array}$ & 7.3 & 2.0 & 0.2 & 2.1 & 0.2 & 1 & -0.03 & -0.03 & -0.06 & -0.08 & -0.06 & 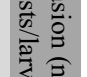 \\
\hline Trichuris sp. & $22.5 * *$ & $11.9 *$ & 1.6 & $4.1^{*}$ & $74.9 * *$ & 0.2 & 1 & $0.47 * *$ & $0.15^{*}$ & $0.22 * *$ & $0.29 * *$ & है \\
\hline Moniezia spp. & $11.9 *$ & $14.7 *$ & 1.9 & 0.8 & $41.6 * *$ & 0.3 & $71.2 * *$ & 1 & 0.09 & $0.15^{*}$ & $0.20 * *$ & $\stackrel{9}{0}$ \\
\hline Eimeria spp. & 7.4 & $12.5^{*}$ & 0.06 & $35.6 * *$ & $5.8^{*}$ & 1.1 & $4.5^{*}$ & $4.7 *$ & 1 & 0.01 & 0.04 & \\
\hline $\begin{array}{l}\text { Fasciola } \\
\text { hepatica }\end{array}$ & $27.7 * *$ & 3.0 & 2.3 & $3.7^{*}$ & $5.1 *$ & 1.2 & $5.6^{*}$ & 2.6 & 1.0 & 1 & $0.33 * *$ & \\
\hline $\begin{array}{l}\text { Dictyocaulus } \\
\text { viviparus }\end{array}$ & $81.7 * *$ & $59.2 * *$ & 0.6 & $11.7 *$ & $16.0 * *$ & 1.2 & $22.1 * *$ & $9.6^{*}$ & 2.3 & $18.2 * *$ & 1 & \\
\hline
\end{tabular}

Prevalence (presence/absence of parasite)

* - P value between 0.05 and 0.001 ; * $-\mathrm{P}<0.001$; in lower left corner in white $-\chi^{2}$ for the prevalence study; in upper right corner - KruskalWallis $\chi^{2}$ values in darker grey and Spearman $\rho$ values in lighter grey below for the intensity of invasion (number of eggs/oocysts/larvae) 
Table 4. Mixed-effect generalised linear model (GLM) coefficients for the effects of season and origin on the intensity of individual parasite invasion in European bison

\begin{tabular}{|c|c|c|c|c|c|c|c|c|}
\hline & \multicolumn{4}{|c|}{ Origin (forest) } & \multicolumn{3}{|c|}{ Season } & \multirow[b]{2}{*}{ Intercept } \\
\hline & $\mathrm{BiF}$ & $\begin{array}{l}\mathrm{BiF} \\
\text { neighbouring } \\
\text { area }\end{array}$ & $\mathrm{KnF}$ & $\mathrm{BoF}$ & Autumn & Winter & Spring & \\
\hline \multicolumn{9}{|l|}{ Trichostrongylidae } \\
\hline Coefficient $\beta$ & 过 & 0.50 & -0.48 & -1.7 & $\ddot{E}$ & 0.95 & 2.16 & 2.69 \\
\hline Standard error & $\overrightarrow{\bar{d}}$ & 0.02 & 0.02 & 0.05 & $\bar{d}$ & 0.03 & 0.02 & 0.02 \\
\hline z statistic & $\stackrel{\rightleftarrows}{\circlearrowright}$ & 27.2 & -19.0 & -30.8 & 岕 & 33.11 & 106.4 & 127.3 \\
\hline $\mathrm{P}>|\mathrm{z}|$ & & $<0.001$ & $<0.001$ & $<0.001$ & & $<0.001$ & $<0.001$ & $<0.001$ \\
\hline \multicolumn{9}{|l|}{ Aonchotheca sp. } \\
\hline Coefficient $\beta$ & $\ddot{g}$ & -0.34 & -3.10 & -0.75 & & -1.18 & -0.23 & 1.94 \\
\hline Standard error & ల్ & 0.06 & 0.18 & 0.12 & 过 & 0.10 & 0.07 & 0.04 \\
\hline z statistic & $\stackrel{0}{0}$ & -5.38 & -17.14 & -6.11 & 边 & -11.20 & -3.30 & 47.9 \\
\hline $\mathrm{P}>|\mathrm{z}|$ & & $<0.001$ & $<0.001$ & $<0.001$ & 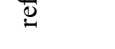 & $<0.001$ & $<0.001$ & $<0.001$ \\
\hline \multicolumn{9}{|l|}{ Nematodirus spp. } \\
\hline Coefficient $\beta$ & $\ddot{\circlearrowright}$ & 3.33 & -0.25 & -12.55 & $\underset{\circlearrowright}{~}$ & 2.05 & 0.53 & -3.87 \\
\hline Standard error & ల్ & 0.35 & 0.80 & 614.7 & లี & 0.22 & 0.24 & 0.38 \\
\hline z statistic & $\frac{\vec{य}}{d}$ & 9.44 & -0.32 & -0.02 & $\frac{\bar{\omega}}{d}$ & 9.00 & 2.20 & -10.21 \\
\hline $\mathrm{P}>|\mathrm{z}|$ & & $<0.001$ & 0.75 & 0.98 & & $<0.001$ & 0.03 & $<0.001$ \\
\hline \multicolumn{9}{|l|}{ Trichuris sp. } \\
\hline Coefficient $\beta$ & $\ddot{\Xi}$ & 2.18 & -0.82 & -16.49 & ¿্ট & 1.76 & 1.71 & -0.36 \\
\hline Standard error & 己 & 0.06 & 0.14 & 481.7 & ల] & 0.07 & 0.06 & 0.08 \\
\hline z statistic & $\stackrel{\bar{\omega}}{0}$ & 33.27 & -5.93 & -0.03 & $\stackrel{\bar{\omega}}{d}$ & 25.72 & 29.45 & -4.69 \\
\hline $\mathrm{P}>|\mathrm{z}|$ & & $<0.001$ & $<0.001$ & 0.97 & & $<0.001$ & $<0.001$ & $<0.001$ \\
\hline \multicolumn{9}{|l|}{ Moniezia spp. } \\
\hline Coefficient $\beta$ & & 1.95 & 1.21 & -16.1 & & 1.51 & 1.74 & -0.43 \\
\hline Standard error & U & 0.07 & 0.08 & 414.4 & U & 0.08 & 0.06 & 0.08 \\
\hline z statistic & 选 & 26.61 & 14.23 & -0.04 & $\stackrel{0}{\frac{0}{2}}$ & 19.60 & 31.57 & -5.34 \\
\hline $\mathrm{P}>|\mathrm{z}|$ & & $<0.001$ & $<0.001$ & 0.97 & & $<0.001$ & $<0.001$ & $<0.001$ \\
\hline \multicolumn{9}{|l|}{ Eimeria spp. } \\
\hline Coefficient $\beta$ & ¿ु & 0.76 & -1.62 & 1.25 & $\ddot{\circlearrowright}$ & -0.99 & -0.59 & 4.10 \\
\hline Standard error & 巳ี & 0.02 & 0.03 & 0.02 & ల్ల & 0.03 & 0.02 & 0.01 \\
\hline z statistic & $\stackrel{0}{0}$ & 45.62 & -50.10 & 60.05 & $\stackrel{0}{0}$ & -34.66 & -35.12 & 305.10 \\
\hline $\mathrm{P}>|\mathrm{z}|$ & & $<0.001$ & $<0.001$ & $<0.001$ & & $<0.001$ & $<0.001$ & $<0.001$ \\
\hline \multicolumn{9}{|l|}{ Fasciola hepatica } \\
\hline Coefficient $\beta$ & $\ddot{U}$ & 0.20 & -0.77 & -0.16 & ¿্త & 1.42 & 0.65 & 1.44 \\
\hline Standard error & 巳ี & 0.05 & 0.07 & 0.09 & ల్ี & 0.05 & 0.05 & 0.04 \\
\hline z statistic & $\stackrel{\vec{य}}{\vec{J}}$ & 4.21 & -10.30 & -1.71 & 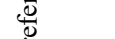 & 27.33 & 12.27 & 32.17 \\
\hline $\mathrm{P}>|\mathrm{z}|$ & & $<0.001$ & $<0.001$ & 0.09 & $=$ & $<0.001$ & $<0.001$ & $<0.001$ \\
\hline \multicolumn{9}{|l|}{ Dictyocaulus viviparus } \\
\hline Coefficient $\beta$ & 8 & 2.21 & -19.31 & 1.54 & 8 & 1.26 & 1.40 & 0.82 \\
\hline Standard error & อี리 & 0.04 & 770.34 & 0.06 & อี & 0.04 & 0.03 & 0.04 \\
\hline z statistic & 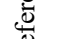 & 51.89 & -0.03 & 27.65 & एँّ & 29.94 & 43.70 & 18.00 \\
\hline $\mathrm{P}>|\mathrm{z}|$ & 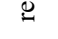 & $<0.001$ & 0.98 & $<0.001$ & $\circlearrowright$ & $<0.001$ & $<0.001$ & $<0.001$ \\
\hline
\end{tabular}

Table 5. Mixed-effects generalised linear model (GLM) coefficients for the effects of season and origin on the probability of European bison of being infected with individual parasites

\begin{tabular}{|c|c|c|c|c|c|c|c|c|}
\hline & \multicolumn{4}{|c|}{ Origin (forest) } & \multicolumn{3}{|c|}{ Season } & \multirow[b]{2}{*}{ Intercept } \\
\hline & $\mathrm{BiF}$ & $\begin{array}{l}\text { BiF } \\
\text { neighbouring } \\
\text { area } \\
\end{array}$ & $\mathrm{KnF}$ & $\mathrm{BoF}$ & Autumn & Winter & Spring & \\
\hline \multicolumn{9}{|l|}{ Aonchotheca sp. } \\
\hline Coefficient $\beta$ & $\underset{U}{=}$ & 0.22 & -2.96 & -0.79 & ¿ & -0.90 & -0.84 & 0.58 \\
\hline Standard error & $\stackrel{0}{0}$ & 0.29 & 0.42 & 0.47 & 巳ี & 0.34 & 0.30 & 0.21 \\
\hline z statistic & 苞 & 0.77 & -7.01 & -1.68 & $\frac{\overrightarrow{0}}{2}$ & -2.65 & -2.78 & 2.73 \\
\hline $\mathrm{P}>|\mathrm{z}|$ & & 0.44 & $<0.001$ & 0.09 & & 0.008 & 0.005 & 0.006 \\
\hline \multicolumn{9}{|l|}{ Trichuris sp. } \\
\hline Coefficient $\beta$ & ¿્ల & 1.20 & -0.95 & 0 & $\ddot{\circlearrowright}$ & 1.13 & 1.30 & -3.47 \\
\hline Standard error & ల్ & 0.49 & 0.84 & - & ల్ & 0.60 & 0.49 & 0.49 \\
\hline z statistic & $\frac{\bar{\omega}}{\Delta}$ & 2.44 & -1.13 & - & $\underset{\omega}{0}$ & 1.88 & 2.68 & -6.96 \\
\hline $\mathrm{P}>|\mathrm{z}|$ & & 0.02 & 0.26 & - & & 0.06 & 0.007 & $<0.001$ \\
\hline \multicolumn{9}{|l|}{ Dictyocaulus viviparus } \\
\hline Coefficient $\beta$ & 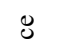 & 1.05 & 0 & 0.21 & 8 & 0.75 & 2.29 & -1.67 \\
\hline Standard error & $\overline{0}$ & 0.32 & - & 0.53 & य] & 0.38 & 0.36 & 0.27 \\
\hline z statistic & $\frac{\overrightarrow{0}}{2}$ & 3.26 & - & 0.40 & 这 & 1.98 & 6.35 & -6.23 \\
\hline $\mathrm{P}>|\mathrm{z}|$ & 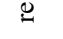 & 0.001 & - & 0.69 & 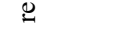 & 0.05 & $<0.001$ & $<0.001$ \\
\hline
\end{tabular}

In the final mixed-effect GLM, the fact that European bison originated from the neighbouring area of the Białowieża Forest increased the likelihood of more intense invasions of Trichostrongylidae, Nematodirus spp., Trichuris sp., Moniezia spp., Eimeria spp., Fasciola hepatica, and Dictyocaulus viviparus in 
comparison with the animals living inside the forest (Table 4). Origin of the European bison from either of the two populations in the Knyszyńska or Borecka Forests lowered the risk of most parasite invasions. The season change also had a significant effect on the parasite content in the faeces. In most cases, there was intensification of invasions from autumn levels to winter and spring levels, except for Aonchotheca sp. and Eimeria spp., invasions of which were more likely to weaken from autumn towards spring. We were able to develop three prevalence models of invasion for Aonchotheca sp., Trichuris sp., and D. viviparus (Table 5). As we can interpret from them, the risk of Aonchotheca sp. infection decreased significantly in the Knyszyńska Forest and in winter and spring. The probability of the European bison being infected with Trichuris sp. and D. viviparus increased outside but near the Białowieża Forest seen against the probability inside the forest, and increased substantially in winter and even more in spring.

\section{Discussion}

Parasitic invasions are the most common pathological factors and the easiest to diagnose, also in the field, of those which can affect the health of freeliving animals (18). The study involved free-living European bison from the same region of Poland but managed differently. The animals from the Białowieża Forest and the Borecka Forest stay all year round in a compact forest complex and rarely leave it. In winter, they are fed regularly. Moreover, the European bison from the Borecka Forest are more plentifully fed as, in addition to hay and haylage, they also receive concentrated feed. European bison living in the Białowieża Forest are fed only with roughage, ensuring the minimum nutrition to sustain life (2). In the winter season, European bison from the neighbouring of Białowieża Forest and those from the Knyszyńska Forest live in a mosaic area. During the vegetation season and while resting, they stay in more or less dense forest complexes, while in winter they often feed in designated places in the forest where haystacks are prepared, or in open areas of farmland, where they often cause losses to agriculture (21). The results of the presented research show that parasitological monitoring may serve as one of the indicators of the hygiene of winter feeding places. Conducting research on freeliving animals may be affected by a certain error because each collection of samples in the field does not ensure that they are collected from different individuals. In the described study, this risk was minimised by involving staff experienced in working with European bison in sample collection. The variability of invasion intensity was observed previously by other researchers and was related to the mode of feeding, sex, and season of the year (1). The highest invasion intensity expressed in the number of eggs, larvae, and oocysts excreted was observed in spring in the Białowieża Forest due to the concentration of animals in feeding places. An additional factor influencing the rise in the number of invasive forms excreted is the phenomenon of spring dispersion of parasites (3). This was observed especially in the testing of winter E. bison samples from the Białowieża Forest and the surrounding area. The statistically significant differences in the intensity of invasion to the disadvantage of the European bison from the area contiguous to the Białowieża Forest are presented both in Fig. 1 and in Table 4. The end of the growing season is the period when the animals are in the best condition, which is conducive to lower extensiveness and intensity of invasion. Because the most intense parasite invasions were observed in the European bison living in the Białowieża Forest neighbouring area, this possibly suggests higher exposure to parasites driven by such circumstances as increased animal density, direct contact through feeding together at hay barracks and haystacks, and continuous contamination of hay with faeces. The feeding-related danger is amplified by the long time during which the animals stay in the feeding place, which increases possible exposure risk. In addition, the European bison which leave the Białowieża Forest have increased contact with other ruminants, especially domestic ones. In animals fed successively, the intensity of infection was lower because hay and haylage are delivered several times a week (10). In the case of the Borecka Forest, feed is given daily. Also in animals fed on farmland (the western European bison herd from the Białowieża Forest and Knyszyńska Forest), no statistically significant higher levels of parasitic invasion were observed. This is probably due to roving of the European bison which feed in different places every day because they are chased away by the farmers. One of the examples of a procedure aimed at limiting the spread of parasites among European bison during winter feeding in the Białowieża National Park is provision of fresh hay or haylage several times a week and cleaning of uneaten remains of feed and accumulated excrement at the beginning of spring in every feeding place. This also ensures that the nutritional value of the feed is preserved and the sanitary and hygienic standards are not failed at the feeding places.

From the European bison health and husbandry point of view, the most important element is prevention, i.e. preventing a significant increase in parasitic invasion by developing winter feeding methods for E. bison, especially in the area of the Białowieża and Knyszyńska Forests, where the risk of contaminated feed infection is the greatest. Based on the results of research on samples coming from the European bison from the Borecka Forest, it appears that concentrated feed as an addition to roughage can cause slower passage of feed content through the digestive tract and consequent multiplication of coccidia (27). Despite this, the intensity of European bison parasite infection in the three forests was quite low and did not exceed 500 eggs, 
larvae, and oocysts in $1 \mathrm{~g}$ of the studied sample, which is a correspondent limit above which clinical signs of invasion can be observed $(7,23)$. The highest diversity of the parasites was observed in the Białowieża Forest, where the eggs of the gastrointestinal nematodes of the genera Trichuris, Nematodirus, and Aonchotheca of the Trichostrongylidae family, eggs of the liver fluke Fasciola hepatica, pulmonary nematode larvae of Dictyocaulus viviparous, and oocysts of the genus Eimeria were found. In the Knyszyńska Forest, there are also nematodes of the genera Aonchotheca and Strongyloides of the Trichostrongylidae family, as well as liver fluke and coccidia. D. viviparus pulmonary nematodes were not detected there. However, a similar composition of parasites was observed in the Borecka Forest. Strongyloides were not found there, whereas lung $D$. viviparus nematodes did occur and the first case of Ashworthius sidemi invasion was described on this terrain in 2018 (6). It should be noted that both the prevalence and number of larvae of pulmonary nematodes in the Knyszyńska Forest are low, while in the Białowieża Forest larvae were observed in most of the tested samples, and their number could reach several hundred specimens in one sample (24). Quite numerous eggs of Moniezia tapeworms were also observed in individual European bison in the Knyszyńska and Białowieska Forests. This applied most often to juvenile bison with incompletely developed immune mechanisms (26). However, the level of European bison infection observed in the three forests does not indicate the possibility of clinical symptoms, even during the spring dispersion of invasive parasites (15). It is worth noting that in the Knyszyńska and Białowieża Forests the liver fluke $F$. hepatica occurred in most of the tested samples, but the number of eggs was quite low. From the public health protection point of view, it is important information that in north-eastern Poland invasions of liver fluke among free-living ruminants are common (5) because humans could become an accidental host by drinking e.g. water or eating plants contaminated with invasive forms $(14,29)$. Fasciolosis is a zoonosis and can be a real threat to human health, and due to the unusual symptoms and rarity of human infection, it can be a diagnostic and therapeutic problem (28). One of the conservation tasks enshrined in the Protection Plan for the Białowieża National Park is identifying threats to the health of the free-living European bison, among which the high burden of parasitic infections should be considered significant. Therefore, there are veterinary activities aimed at preventing parasite invasion and combating their occurrence (25). The health status of European bison is assessed by veterinarians making direct observations and interpreting the results of additional laboratory tests. The level of European bison infection observed in three forests does not indicate any important clinical implications nor the need for deworming $(17,18)$. This is primarily because in freeliving animals it is not possible to apply a precise dose of chemotherapeutic agents, which may lead to drug resistance (25). In addition, it may also cause environmental contamination, which may influence the biodiversity of other invertebrates such as arthropods and the whole habitat. It was described that the use of anthelmintic drugs in animals kept on meadows and pastures may cause an increase in the mortality rate of coprophagous beetles (20). As a consequence, besides the harm to the population of beetles, absence of these insects results in the cessation of the removal of faeces by them and increases the prolonged risk of animal exposure to the parasites in excrement. Parasitological monitoring is also crucial for the emerging new threats to European bison health, such as the parasite of abomasum Ashworthius sidemi spreading among freeliving ruminants (11).

In conclusion, parasitological monitoring is one of the methods of sanitary and hygienic assessment of winter feeding places, as it shows the distribution and prevalence of parasitic invasions. The presented analysis indicates risk factors which may be key topics to address for better practice in European bison management. Such monitoring should be systematically conducted on a representative number of samples and should then give the managers of European bison herds the opportunity to maintain health surveillance of free-living members of the species.

Conflict of Interest Statement: The authors declare that there is no conflict of interests regarding the publication of this article.

Financial Disclosure Statement: This study was financed by the project "The development of the European bison meta-population in north-eastern Poland" funded by the EEA and Norway (No 570/2014/Wn-14/OP-XN-02/D), while the publishing fee was covered from Białowieża National Park funds.

Animal Rights Statement: None required.

\section{References}

1. Albery G.F., Kenyon F., Morris A., Morris S., Nussey D.H., Pemberton J.M.: Seasonality of helminth infection in wild red deer varies between individuals and between parasite taxa. Parasitology 2018, 145, 1410-1420. doi: 10.1017/S003118201 8000185.

2. Białowieża National Park: Winter feeding. https://bpn.com.pl/ index.php?option $=$ com_content\&task $=$ view\&id $=60 \&$ Itemid $=111$ \&lang=en.

3. Bowman D.D.: Georgi's Parasitology for Veterinarians. $9^{\text {th }}$ edition. W.B. Saunders, Philadelphia, 2009, pp. 464.

4. Demiaszkiewicz A.W.: Helminthes and helminthoses of wild animals. Kosmos, 2005, 54, 61-71.

5. Demiaszkiewicz A.W.: Przywry pasożytujące w wątrobie u żubrów w Puszczy Białowieskiej. Magazyn Wet 2006, 15, $72-74$.

6. Demiaszkiewicz A.W., Bielecki W., Rodo A., Pyziel A.M., Filip K.J.: Parasitofauna of European bison Bison bonasus (L.) in Borecka Forest. Med Weter 2018, 74, 253-256. 
7. Demiaszkiewicz A.W., Pyziel A.M., Lachowicz J.: Helminthological status of European bison in Białowieża Forest in the winter 2007/2008. Europ Bison Conserv Newsletter 2008, $1,42-52$.

8. Dohoo I., Martin W., Stryhn H.: Veterinary Epidemiologic Research, Charlottetown, 2010.

9. Dróżdż J.: A study on helminths and helminthiases in bison, Bison bonasus (L.) in Poland. Acta Parasitol Pol 1961, 9, 55-96.

10. Dróżdż J., Demiaszkiewicz A.W., Lachowicz J.: Nematodes of large intestine of European bisons. Wiad Parazytol 1990, 36, 35-38.

11. Dróżdż J., Demiaszkiewicz A.W., Lachowicz J.: Aswortiosis a new parasitosis of wild ruminants. Med Weter 2000, 56, 32-35.

12. Dróżdż J., Demiaszkiewicz A.W., Lachowicz J.: Forming of gastro-intestinal nematodes fauna of free ranging European bisons in Białowieża Primeval Forest during last 17 years (1984-2001). Wiad Parazytol 2002, 48, 375-381.

13. Gundłach L.J., Sadzikowski A.B.: Diagnostyka i zwalczanie inwazji pasożytów u zwierząt. WAR Lublin 2005, pp. 7-18.

14. Kim A.J., Choi C.H., Choi S.K., Shin Y.W., Park Y-K., Kim L., Choi S.J., Han J.Y., Kim J.M., Chu Y.Ch., Park I.S.: Ectopic human Fasciola hepatica infection by an adult worm in the mesocolon. Korean J Parasitol 2015, 53, 725-730.

15. Krzysiak M.K.: The evaluation of selected infectious and invasive agent prevalence in the population of European bison (Bison bonasus) in Poland. Doctoral thesis, University of Life Sciences, Lublin, 2017, pp. 21-35.

16. Krzysiak M.K., Dackiewicz J., Kęsik-Maliszewska J., Larska M.: Post-mortem evaluation of pathological lesions in European bison (Bison bonasus) in the Białowieża Primeval Forest between 2008 and 2013. Bull Vet Inst Pulawy 2014, 58, 421-431.

17. Krzysiak M.K., Demiaszkiewicz A.W., Lachowicz J., Pyziel A.M., Kuligowska I.: Efficacy of antihelmintic treatment of European bisons in Bialowieza National Park Breeding Center. Życie Wet 2012, 87, 47-48.

18. Krzysiak M.K., Demiaszkiewicz A.W., Pyziel A.M., Larska M. Parasitological monitoring in the European Bison Breeding Center of Bialowieza National Park. Med Weter 2015, 71, 791-795.

19. Krzysiak M.K., Larska M., Dackiewicz J., Anusz K.: Restitution of European bison (Bison bonasus) in Białowieża and the most common health problems of the species in the wild and captive populations in Poland. Natl Parks Nature Reserves 2018, 37, 85-91.

20. Manning P., Beynon S.A., Lewis O.T.: Quantifying immediate and delayed effects of anthelmintic exposure on ecosystem functioning supported by a common dung beetle species. PLOS One. 2017, 12, e0182730.

21. Olech W., Sobczuk M.: Straty i szkody wyrządzane przez dzikie zwierzęta w gospodarce rolnej, leśnej i rybackiej. Szkody powodowane przez żubry w lasach i uprawach rolnych. Monograph, edited by Zalewski D., University of Warmia and Mazury in Olsztyn, Olsztyn, 2018, pp. 67-75.

22. Order of Polish Minister of Environment of November 7, 2014 regarding establishment of protection plan of Białowieża National Park, Journal of Laws 2014, pos. 1735.

23. Osińska B., Demiaszkiewicz A.W., Lachowicz J.: Pathological lesions in European bison (Bison bonasus) with infestation by Ashworthius sidemi (Nematoda, Trichostrongylidae). Pol J Vet Sci 2010, 13, 63-67.

24. Pyziel A.M.: Molecular analysis of lungworms from European bison (Bison bonasus) of the basis of small subunit ribosomal RNA gene (SSU). Acta Parasitol 2014, 59, 122-125.

25. Pyziel A.M., Björk S., Wiklund R., Skarin M., Demiaszkiewicz A.W., Höglund J.: Gastrointestinal parasites of captive European Bison (Bison bonasus (L.) with a sign of reduced efficacy of Haemonchus contortus to fenbendazole. Parasitol Res 2017, 17, 295-302.

26. Pyziel A.M., Demiaszkiewicz A.W., Lachowicz J., Kuligowska I.: Case of plugging small intestine in European bison by Cestoda Moniezia benedeni. Abstracts of VII International Conference " 80 years of bison restitution in the Białowieża Forest". Białowieża 2009, pp. 51-52.

27. Pyziel A.M., Jóźwikowski M., Demiaszkiewicz A.W.: Coccidia (Apicomplexa: Eimeridae) of the lowland European bison Bison bonasus bonasus. Vet Parasitol 2014, 202, 138-144.

28. WHO Fascioliasis. https://www.who.int/foodborne_trematode infections/fascioliasis/en.

29. Winkelhagen A.J.S., Mank T., de Vries P.J., Soetekouw R.: Apparent triclabendazole-resistant human Fasciola hepatica infection, the Netherlands. Emerging Infect Dis 2012, 18, 1028-1029. 